\title{
A Rare Case of Parasitic Myoma: Possible Etiologies and Review of the Literature
}

\author{
Nadir Bir Parazitik Miyom Olgusu: \\ Olası Nedenler ve Literatür Derlemesi
}

Enes TAYLAN, ${ }^{a}$

Çağdaş ŞAHIN, ${ }^{a}$

Ali AKDEMIR, ${ }^{a}$

Ahmet Özgür YENIEL ${ }^{a}$

${ }^{a}$ Department of Obstetrics and Gynecology, Ege University Faculty of Medicine, İzmir

Geliş Tarihi/Received: 18.03.2015

Kabul Tarihi/Accepted: 24.09 .2015

Yazışma Adresi/Correspondence:

Enes TAYLAN

Ege University Faculty of Medicine, Department of Obstetrics and Gynecology, İzmir,

TURKEY/TÜRKIYE

drayeniel@ hotmail.com
Copyright $\odot 2017$ by Türkiye Klinikleri

\begin{abstract}
Uterine myoma is the most common benign gynecologic pathology and the most common indication for hysterectomy. Parasitic myoma is a very rare subclass of this pathology. The frequency of parasitic myomas is unknown. Although several theories proposed for the etiology of spontaneous parasitic myoma, currently it appears as an increasing complication of laparoscopic morcellation of uterus or myoma. Thus, these are named as iatrogenic parasitic myomas. The treatment of parasitic myomas can be very difficult due to vascular and adjacent organ involvement such as mesentery and bowels. In this case report we aimed to present a case of spontaneous parasitic myoma in a patient without history of uterine surgery and, examine the possible etiologies and prevention techniques of parasitic myomas with a review of the literature.
\end{abstract}

Keywords: Leiomyoma; laparoscopy; iatrogenic disease

ÖZET Uterin miyomlar, en sık rastlanan benign jinekolojik patolojilerdir ve kadınlarda histerektominin en sık nedenidir. Parazitik miyomlar bu patolojinin çok nadir bir alt sınıfıdır. Kendiliğinden (herhangi bir uterin cerrahiye sekonder olmayan) gelişen parazitik miyomların sıklığı tam olarak bilinmemektedir. Etiyolojiye yönelik çok sayıda teori ileri sürülmesine karşın günümüzde özellikle uterus ve miyomların laparoskopik morselasyonunun bir komplikasyonu olarak karşımıza çıkmaktadır. Bu şekilde gelişen miyomlar iyatrojenik parazitik miyom olarak kabul edilirler. Parazitik miyomların tedavisi vasküler, barsak ve mezenter invazyonu gibi nedenlerle bazen çok zor olabilmektedir. Bu olgu raporu ile geçirilmiş herhangi bir uterin cerrahi öyküsü olmayan (spontan) parazitik miyom saptanan bir hastayı sunmak, parazitik miyomların olası nedenlerini ve önlemeye yönelik yaklaşımları literatür derlemesi eşliğinde incelemeyi amaçladık.

Anahtar Kelimeler: Leiomiyom; laparoskopi; iyatrojenik hastalık

U -terine myomas are the most common benign gynecological tumors and are reported on pathologic examination in approximately $80 \%$ of surgically excised uteri. ${ }^{1}$ A very rare type of uterine myoma is parasitic myoma, which is first described by Kelly and Cullen in 1909, and postulated as a pedunculated subserosal myoma for some reason partially or completely separates from uterus and receives its blood supply from another source. ${ }^{2,3}$ However, the developmental pathophysiology and nature of parasitic myomas are still uncertain.

Current literature of parasitic myoma is limited to a small number of case reports and besides, rather than the conventional theory of Kelly and 
Cullen, most of these cases are reported as a consequence of laparoscopic morcellation procedures. ${ }^{4-10}$ In this study we aimed to present a very rare case of spontaneous parasitic myoma in a patient without history of uterine surgery and examine the proposed etiologies together with possible prevention methods.

\section{CASE REPORT}

A 44-year-old multiparous woman with complaints of pelvic pain and constipation referred to our clinic because of a right adnexal mass. Patient history was unremarkable. On pelvic examination, uterus was large and a mobile and well-demarcated solid mass palpated on the right side. Laboratory tests and tumor markers were normal. Transvaginal ultrasound revealed a homogenous, right adnexal mass $9 \mathrm{~cm}$ in diameter which was likely to be benign. During laparoscopic surgery a parasitic myoma connected to the mesentery of transverse colon without any connection to ovary or uterus observed. After a detailed exploration the peduncle of the myoma ligated and separated from mesentery, subsequently open power morcellation and abdominal irrigation in order to prevent remaining tissue fragments performed (Figure 1). No intraoperative or postoperative complications were recorded. Histopathology confirmed the diagnosis of leiomyoma. During the two years of follow up no clinical or sonographic recurrence was recorded.

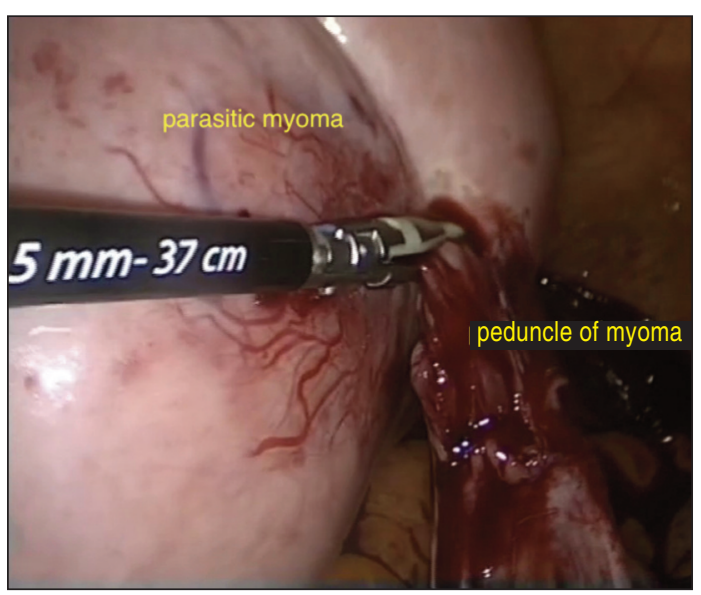

FIGURE 1: Ligation of peduncle of parasitic myoma and separation from small intestine.

\section{DISCUSSION}

Parasitic myoma is a very rare class of uterine myomas. The conventional explanation for this condition originally proposed by Kelly and Cullen and supported by Brody as a pedunculated subserosal myoma separates from the uterus and receives an extrauterine blood supply such as from mesentery, bowel or peritoneum. ${ }^{2,3}$ This theory explains the possible etiology of spontaneous parasitic myomas.

The second theory is based on the idea of metaplasia, which is suggested by Tavassoli and Norris in their study of 20 cases of leiomyomatosis peritonealis disseminata. ${ }^{4}$ They hypothesized subperitoneal mesenchymal stem cells may undergo metaplasia by the stimulation of estrogen and differentiate into myofibroblast. This theory is supported by some case reports of patients after tamoxifen treatment, hormone replacement therapy or prolonged oral contraceptive usage..$^{5-7}$

Third proposed theory is based on genetic analysis that emphasizes the importance of somatic mutations particularly affecting MED 12, a subunit of mediator complex regulates transcription initiation and elongation in gene promoters to the RNA polymerase II initiation complex. ${ }^{8,9}$

All these theories are suggested as possible etiologies for spontaneous parasitic myomas. In our case, the parasitic myoma may be explained by the first theory proposed by Kelly and Cullen, because the patient had no history of uterine surgery. However, the literature consists mainly of parasitic myomas occur after laparoscopic morcellation of the uterus or myoma. ${ }^{10-15}$ Iatrogenic parasitic myoma cases tend to be increasing due to rising popularity and application of minimally invasive procedures. Although it is difficult to establish a certain frequency due to asymptomatic cases, Cucinella et al. reported the incidence of parasitic myoma after laparoscopic myomectomy with morcellation as $1.2 \% .^{16}$

Laparoscopy is undoubtedly a milestone in the history of modern surgery and morcellation procedure is a crucial step, which enables removal of large tissues from abdominal cavity during la- 
paroscopy. However, recently an increasing number of concerns related with this procedure reported by various authors. These concerns are not only about the increased risk of iatrogenic parasitic myomas but also more alarming complication is tumor spread that worsens the prognosis. ${ }^{17,18}$ Under the influence of these negative reports, US Food and Drug Administration released a safety communication in April 2014, which is discouraging the use of power morcellation during laparoscopy.

As a consequence of these concerns researchers tried to find a technique to decrease or if possible eliminate the problem of tissue dissemination during specimen morcellation. In this frame, in situ morcellation suggested as a possible method to reduce the dissemination of myoma fragments. ${ }^{19}$ However, enclosed or in bag morcellation techniques are probably the most promising result of these endeavors. ${ }^{20-23}$ The main idea underlying these studies is morcellation of the specimen in containment inside the abdominal cavity to isolate morcellation area from abdominal space and reduce the risk of tissue dissemination.

Consequently, although spontaneous parasitic myomas are very rare, particularly iatrogenic type has an increasing incidence as complication of laparoscopic surgery. Besides, the treatment can be very difficult due to vascular and adjacent organ involvement. Detailed exploration for remained tissue fragments and abdominal irrigation may be helpful after laparoscopic morcellation. Additionally, advancements in enclosed morcellation methods hold the promise to overcome this concern.

\section{Conflict of Interest}

Authors declared no conflict of interest or financial support.

\section{Authorship Contributions}

Enes Taylan analyzed the case and drafted the manuscript. Çağdaş Şahin, Ali Akdemir, Ahmet Özgür Yeniel analyzed and interpreted the case, revised the manuscript. All authors reviewed the final manuscript and approved for submission.

\section{REFERENCES}

1. Cramer SF, Patel A. The frequency of uterine leiomyomas. Am J Clin Pathol 1990;94(4):4358.

2. Kelly HA, Cullen TS. Myomata of the Uterus. Philadelphia (PA): WB Saunders; 1909. p. 723.

3. Brody S. Parasitic fibroid. Am J Obstet Gynecol 1953;65(6):1354-6.

4. Tavassoli FA, Norris HJ. Peritoneal leiomyomatosis (leiomyomatosis peritonealis dis- seminata): a clinicopathologic study of 20 cases with ultrastructural observations. Int J Gynecol Pathol 1982;1(1):5974.

5. Sutherland JA, Wilson EA, Edger DE, Powell D. UItrastructure and steroid-binding studies in leiomyomatosis peritonealis disseminata. Am J Obstet Gynecol 1980;136(8):992-6.

6. Heinig J, Neff A, Cirkel U, Klockenbusch W. Recurrent leiomyomatosis peritonealis disseminata after hysterectomy and bilateral salpingooophorectomy during combined hormone replacement therapy. Eur J Obstet Gynecol Reprod Biol 2003;111(2):216-8.

7. Bristow RE, Montz FJ. Leiomyomatosis peritonealis disseminata and ovarian Brenner tumor associated with tamoxifen use. Int J Gynecol Cancer 2001; 11(4):312-5.

8. Mäkinen N, Mehine M, Tolvanen J, Kaasinen E, Li $\mathrm{Y}$, Lahtonen HJ, et al. MED12, the mediator complex subunit 12 gene, is mutated at high frequency in uterine leiomyomas. Science 2011;334(6053): $252-5$.
9. Halama N, Grauling-Halama SA, Daboul I. Familia clustering of leiomyomatosis peritonealis disseminata: an unknown genetic syndrome? BMC Gastroenterol 2005;5(1):33.

10. Paul PG, Koshy AK. Multiple peritoneal parasitic myomas after laparoscopic myomectomy and morcellation. Fertil Steril 2006;85(2):492-3

11. Sinha R, Sundaram M, Mahajan $C$, Sambhus $A$ Multiple leiomyomas after laparoscopic hysterectomy: report of two cases. J Minim Invasive Gynecol 2007;14(1):123-7.

12. Takeda A, Mori M, Sakai K, Mitsui T, Nakamura H Parasitic peritoneal leiomyomatosis diagnosed 6 years after laparoscopic myomectomy with electric tissue morcellation: report of a case and review of the literature. J Minim Invasive Gynecol 2007; 14(6):770-5.

13. Sinha R, Sundaram M, Lakhotia S, Kadam P, Rao $G$, Mahajan C. Parasitic myoma after morcellation. J Gynecol Endosc Surg 2009;1(2):113-5.

14. Kho KA, Nezhat C. Parasitic myomas. Obstet Gynecol 2009;114(3):611-5

15. Huang PS, Chang WC, Huang SC. Iatrogenic parasitic myoma: a case report and review of the literature. Taiwan J Obstet Gynecol 2014;53(3): 392-6.

16. Cucinella G, Granese R, Calagna G, Somigliana E Perino A. Parasitic myomas after laparoscopic surgery: an emerging complication in the use of morcellator? Description of four cases. Fertil Steril 2011;96(2):e90-6.
17. Della Badia C, Karini H. Endometrial stromal sarcoma diagnosed after uterine morcellation in laparoscopic supracervical hysterectomy. J Minim Invasive Gynecol 2010;17(6):791-3.

18. Anupama R, Ahmad SZ, Kuriakose S, Vijaykumar DK, Pavithran K, Seethalekshmy NV. Disseminated peritoneal leiomyosarcomas after laparoscopic "myomectomy" and morcellation. J Minim Invasive Gynecol 2011;18(3):386-9

19. Chang WC, Chou LY, Chang DY, Huang PS Huang SC, Chen SY, et al. Simultaneous laparoscopic uterine artery ligation and laparoscopic myomectomy for symptomatic uterine myomas with and without in situ morcellation. Hum Reprod 2011;26(7):1735-40.

20. Einarsson Jl, Cohen SL, Fuchs N, Wang KC In-bag morcellation. J Minim Invasive Gynecol 2014;21(5):951-3.

21. Cohen SL, Einarsson JI, Wang KC, Brown D, Boruta D, Scheib SA, et al. Contained power morcellation within an insufflated isolation bag. Obstet Gynecol 2014;124(3):491-7.

22. Cohen SL, Greenberg JA, Wang KC, Srouji SS Gargiulo AR, Pozner CN, et al. Risk of leakage and tissue dissemination with various contained tissue extraction (CTE) techniques: an in vitro pilot study. J Minim Invasive Gynecol 2014;21(5):935-9.

23. Akdemir A, Taylan E, Zeybek B, Ergenoglu AM, Sendag F. Innovative technique for enclosed morcellation using a surgical glove. Obstet Gynecol 2015;125(5):1145-9. 